Documento de Trabajo 2017-04

Facultad de Economía y Empresa

Universidad de Zaragoza

Depósito Legal Z-1411-2010. ISSN 2171-6668

\title{
COLLABORATIVE NETWORKS AND EXPORT INTENSITY IN FAMILY FIRMS: A QUANTILE REGRESSION APPROACH
}

\author{
Raúl Serrano ${ }^{(1)}$ \\ Isabel Acero-Fraile ${ }^{(1)}$ \\ Natalia Dejo-Oricain ${ }^{(1)}$
}

(1) Assistant Professor, Department of Business Administration, Faculty of Economy and Business

University of Zaragoza

\begin{abstract}
:
This paper examines if collaborative networks affect the export status and intensity in family firms. We suggest that the network effect is more relevant when the firm has low export intensity because when the firm is in the first stages of internationalization, networks are very useful to provide export resources and to solve common problems. However, this role becomes less relevant when firms show higher export intensity. For the empirical analysis, we use a dynamic Heckman-Probit model, using in the second stage a quantile regression model.
\end{abstract}

\section{KEYWORDS:}

Family Firms; Networks; Internationalization; Export Intensity; Quantile regression.

JEL: F15, M21, N74, Q13

*This study was supported by project grant ECO2016-77-P (AEI/FEDER, UE) and the COMPETE research group (S125; Government of Aragón - Spain- and FEDER).

Corresponding author: Tel: + 34876554989

University of Zaragoza, c/ Gran Vía, nº 2, 50005, Zaragoza, Spain

Email: I. Acero-Fraile: iacero@unizar.es

R. Serrano: raser@unizar.es

Natalia Dejo-Oricain: ndejo@unizar.es 


\title{
COLLABORATIVE NETWORKS AND EXPORT INTENSITY IN FAMILY FIRMS: A QUANTILE REGRESSION APPROACH
}

\begin{abstract}
:
This paper examines if collaborative networks affect the export status and intensity in family firms. We suggest that the network effect is more relevant when the firm has low export intensity because when the firm is in the first stages of internationalization, networks are very useful to provide export resources and to solve common problems. However, this role becomes less relevant when firms show higher export intensity. For the empirical analysis, we use a dynamic Heckman-Probit model, using in the second stage a quantile regression model.
\end{abstract}

\section{KEYWORDS:}

Family Firms; Networks; Internationalization; Export Intensity; Quantile regression.

JEL: F15, M21, N74, Q13 


\section{Introduction}

The intense globalisation process of economic activity presents a great opportunity for family firms (FFs). They can engage in a range of different internationalization strategies, but exporting is considered the most common foreign market entry mode due to the minimal business risk and resources required (Leonidou and Katsikeas 1996). Specifically, offering goods and services outside the home country provides fruitful growth opportunities, gives successive generations employment opportunities, increases distributed profits, that is the dividends (Claver, Rienda, and Quer 2009), or even promotes the family name around the world (Zahra 2003; Sciascia, Mazzola, Astrachan, and Pieper 2013).

But entering international markets is not always easy for FFs. Reasons like the small size, the scarcity of financial, human and technical resources and the lack of dimension to take advantage of economies of scale have been mentioned as important elements in dealing with international markets (Gómez-Mejía, Haynes, NuñezNickel, Jacobson, and Moyano-Fuentes 2007). Some researchers as Pukall and Calabro (2014) suggest that FFs are able to compensate most of their weaknesses regarding internationalization through family-specific resources as social capital. In this context, confidence between members, repute and social pressure can positively influence relationship of the FF with its environment, included customers, suppliers, business partners, as well as other institutions and establish in this way cooperation networks (Calabro and Mussolino 2011; Segaro 2010; Zahra 2003). So, insidership in relevant networks plays an important role for successful internationalization (Cesinger, Hughes, Mensching, Bouncken, Fredrich, and Kraus 2016; Zaefarian, Eng, and Tasavori 2016).

Networks can help firms acquire knowledge of foreign markets, institutions, rules and regulations (Coviello and Munro 1997; Johanson and Mattson 1988), and, therefore, collaborative networks (a solution between the organization and the market) reduce some of the previous shortcomings and provide a basis to promote growth, expand resources, and increase business opportunities (Sorenson, Folker, and Brigham 2008), facilitating the internationalization of FFs. Following network model, often used in case of family business researches, the internationalization is related to the development of network ties with other firms belonging to a network in a foreign markets what facilitate foreign market entry (Ruzzier, Antončič, and Konečnik 2006; Zaniewska 2012).

Despite the growing interest in the links between FF and the environment and internationalization, it is still necessary deepen the role of networks in the internationalization process of FFs (Kontinen and Ojala 2011a, 2011b). Our paper seeks to contribute to the FFs and internationalization literature by analyzing the networks effect on export activity in FFs. In this sense, the newest aspect and therefore the greatest contribution of our study is analyze if the effect of the collaboration networks is different attending the grade of family firm 
internationalization. The results of our paper show how different types of collaboration networks (commercial and technological) affect positively to the internationalization of the FFs. Moreover, we can see that the FF looks for network economies in the first stages of the internationalization process, when the firm has low export intensity, and it is more independent when it shows an advanced export status and it has acquired experience in the international markets. We believe, on the one hand, that further study of the effect of different types of networks in FF internationalization is an interesting contribution. On the other hand, we use a novel methodology to analyze the effect of networks in different stages of internationalization process. In this sense, for the empirical analysis, this paper uses a dynamic Heckman-Probit model, which corrects problems associated with selection bias. The first stage includes the key factors behind the export market entry decision. The second stage analyses the effect of cooperation mechanisms on export intensity using a quantile regression, which shows the networks effect on the export intensity at different points of the degree of internationalization of the firm.

So, following the network view of internationalization, this research tries to answer to the following questions: First, how do the collaborative networks affect the export status in family firms? Networks are being seen as playing a critical role in the internationalization of the firm (Graves and Thomas 2004) because they can help firms acquire knowledge of foreign markets, institutions, rules and regulations (Coviello and Munro 1997; Johanson and Mattson 1988). For that, the first aim of the paper is to analyze the effect of collaborative networks on the initial decision of exporting, in the context of family firms.

And second, is the effect of networks different regarding the degree of internationalization of the firm? In this regard, we suggest that the network effect is more relevant when the firm has low export intensity. Probably this is our main contribution because in today's rapidly changing business environment, few resources are permanently needed. We suggest that when the firm is in the first stages of internationalization, networks are very useful to provide export resources and to solve common problems. This role becomes less relevant when the firm shows higher export intensity because the firm has acquired more knowledge to face the international market on its own.

For the purpose of this study, a longitudinal panel was produced from 2006 to 2012 comprising of 1,572 firms based on data from the Spanish Business Strategies Survey (SBSS).

The rest of the paper will proceed as follows. We begin with a review of existing theory and research. We then turn to present the hypotheses and we follow with the methodology section, which include the sample, variables and statistical methods used in the study. Finally, we present the results of the empirical analysis and the article finishes with the conclusion. 


\section{Theory and Hypotheses: Collaborative Networks and Internationalization in}

\section{Family Firms}

Although it has been argued that FFs possess some family-specific resources that promote internationalization (including human and social capital as well as governance mechanisms) (Merino, Monreal-Pérez, and SánchezMarín 2014) and some family firm attributes can have a beneficial effect on their internationalization, such as familiness, speed in decision-making or long term orientation (Stein 1989; Pearson, Carr, and Shaw 2008), some authors remark that the family influence implies a lack of management expertise and underdeveloped processes and routines concerning internationalization (Graves and Thomas 2006; Menéndez-Requejo 2005).

To overcome resource and skill limitations family firms need alternative mechanisms. In this sense, the cooperation with other firms could be a good instrument which facilitates the expansion abroad (Johanson and Valhne 2009; Mínguez 2010; Pukall and Calabró 2014). Indeed, over the last two decades the use of external networks by firms has increased tremendously (Hagedoorn 2002). In fact, alliance formation is arguably one of the most utilized strategies for resource acquisition and leveraging by small to medium-sized enterprises (Baum, Calabrese, and Silverman 2000), the majority of them are FFs.

Following the network model of internationalization (Johanson and Vahlne 2009), internationalization is related to the development of network ties with other firms belonging to a network in a foreign market (Kontinen and Ojala 2011b). According to Fernández and Nieto (2005), the basis of internationalization is to have different types of resources that allow the firm to expand outside national borders. Family firms are poorly positioned to obtain these resources. In this sense, the participation in collaboration networks and cooperative arrangements may also offer an effective means of internationalization for companies in general and for family firms in particular (Gallo and García-Pont 1996; Fernández and Nieto 2005). The model proposes that a firm can compensate for its limited resources by developing networks (Johanson and Mattson 1988). Moreover, as Kontinen and Ojala (2011a) pointed out, external social capital connects family firms to diverse networks. It is the results of family firms' interactions, communications and relationships with diverse external stakeholders, and it makes it possible to obtain resources from other companies (Arregle, Hitt, Sirmon, and Very 2007). Networks of this kind are needed if the firm wants to innovate and succeed (Kontinen and Ojala 2011a).

There are a set of unique characteristics that differentiate family firms from non-family firms, namely social capital, human capital, survivability capital, patient capital and characteristic governance structures (Sirmon and Hitt 2003). Those five unique resources may contribute to family business activities aimed at international expansion. Regarding the social capital, we use the definition of Nahapiet and Ghoshal (1998, p. 243) who define 
social capital as the "sum of the actual and potential resources embedded within, available through, and derived from the network". Thus, social capital involves relationships between individuals or between organizations (Burt 1997). In fact, Hitt, Ireland, Camp, and Sexton (2001, 2002) suggested that social capital provides information, technological knowledge, access to markets, and to complimentary resources. In this sense, basing on strong social capital, FFs have developed shared language, norms and a high level of trust which enables building effective relationships with suppliers, customers, etc. (Zaniewska 2012). As the family's social capital increases by connecting these diverse social structures, the firm can build more effective relationships with suppliers, customers, and support organization and in so doing, family firms garner resources from their constituencies and networks (for example, knowledge, financial capital, and so forth) (Sirmon and Hitt 2003). Thus, we can conclude that social capital facilitates collaboration between firms (Dyer and Singh 1998). Moreover, following Sirmon and Hitt (2003) "family firms are likely to gain more value from alliances than nonfamily firms due to the richer social capital derived from their generational outlook and their patient capital" (p. 350).

Within the field of international entrepreneurship, network models play an important role (Coviello 2006), as the personal network of the family members can significantly lever internationalization activities (Anderson, Jack, and Dodd 2005; Zaefarian, Eng, and Tasavori 2016). According to Pukall and Calabrò (2014), network ties between family firms as well as ties between individuals (for example, entrepreneurs) play an important role in pursuing international opportunities (Brydon and Dana 2011; Byrom and Lehman 2009; Crick, Bradshaw, and Chaudhry 2006; Wright and Nasierowski 1994; Mustafa and Chen 2010). However, knowledge about the role of networks in the internationalization process of a family firm appears to be still limited (Kontinen and Ojala 2011a, 2011b).

The above arguments lead to the following hypothesis of the study:

H1: The participation in networks has a positive effect on export status.

In addition to the network theory, the Uppsala internationalization model proposes a sequential internationalization process that depends on the gradual accumulation of knowledge of foreign markets (Johanson and Vahlne 1977). In this sense, firms internationalize according to a series of progressive stages: no regular exporting activity; exporting via agents/distributors; and finally, the establishment of overseas subsidiaries (Johanson and Vahlne 1990). Therefore we can expect that the needed resources for the internationalization process are different in each stage. It suggests that although taking part in corporate networks can also contribute to improve national and international competitiveness of the firm (Fernández and 
Nieto 2005), this effect will be more relevant in the earlier stages of the internationalization process. And even more for the case of FFs because they are characterized by their risk-averse nature and limited growth aspirations (Donckels and Frohlich 1991). Therefore, they usually grow incrementally by progressively entering foreign markets with greater psychic distance (Graves and Thomas 2008). It suggests that the role of networks in the process of internationalization of FFs is more relevant in the early stages of the internationalization process. Thus it is expected that the participation in networks will have a positive effect on export performance, and this effect will be diluted as export intensity increases. When family firms internationalize, they do it mainly incrementally, proceeding step by step (Graves and Thomas 2008) and in the early stages the network support is probably more necessary. According to Kontinen and Ojala (2011b) network ties have been seen as major factors in initiating the internationalization process, with firms following their networks to foreign markets. This role becomes less relevant when firms show higher export intensity because firms have acquired more knowledge to face the international market on their own.

The above arguments lead to the following hypothesis of the study:

H2: The positive impact of networks on the export intensity is especially important in the early stages of the internationalization process of family firm

\section{Dataset and Methodology}

\section{Sample and Data}

The present paper studies the effects of networks/collaborations in the internationalization process of family firms. For this purpose, we use a longitudinal panel between 2006 and 2012 comprising of a sample of 1,572 Spanish family firms involved in the manufacturing sector. The sample and variables used in this paper has been drawn from the Spanish Business Strategies Survey (SBSS), an annual survey of Spanish firms' strategies sponsored by the SEPI Foundation, a government institution, with the support of the Spanish Ministry of Industry. Other previous studies have also used, with success, the SBSS to analyze the export activity of Spanish firms (for example: Fernández and Nieto 2005; Merino and Salas 2002).

Regarding the definition of family firm, there is a lack of consensus in the literature (Abdellatif, Amann, and Jaussaud 2010; Benavides-Velasco, Quintana-García, and Guzmán-Parra 2013). This study defines the family firm as family members occupying managerial positions. Following Fernández and Nieto (2005) this definition of the family firm enables us to identify the family's capacity for effective control. 


\section{Dependent Variables}

In order to analyze the effect of networks on the internationalization process, we use a Heckman-Probit dynamic model to control the selection bias problem. Thereby, the first equation includes the determinants of the firm's decision to export while the second equation considers the determinants of export intensity (Serrano, Acero, and Fernández-Olmos 2016).

In this sense, two dependent variables are used in the study to assess the degree of international involvement of family firms: the firm's export status (first equation) and export intensity of exporting firms (second equation).

In the first stage, Export status ( $D_{i, t}^{\exp }$ ) is a dummy variable taking the value one if firm $i$ exported in year $t$ and zero otherwise. In the second stage, the dependent variable, Export Intensity, has been calculated as the ratio export sales over total sales. This measure of export intensity has been widely used in the literature (Fernández and Nieto 2005; Majocchi, Bacchiocchi, and Mayrhofer 2005; Pla-Barber and Alegre 2007; Estrin, Meyer, Wright, and Foliano 2008; Guner, Lee, and Lucius 2010; Reis and Forte 2016, among others).

Table 1

Variables, Measures and Expected Effect on Export Intensity

\begin{tabular}{|c|c|c|}
\hline & & Expected \\
\hline Variable & Description & Sign \\
\hline \multicolumn{3}{|l|}{ Variable Dependent } \\
\hline D_Exp $\left(1^{\text {st }}\right.$ Stage $)$ & Dummy variable- Identifies whether the firm exports & \\
\hline $\begin{array}{l}\text { Export_Intensity } \\
\left(2^{\text {nd }} \text { Stage }\right)\end{array}$ & Export sales / Total Sales & \\
\hline \multicolumn{3}{|l|}{ Independent Variables } \\
\hline Commercial_Network & $\begin{array}{l}\text { Dummy variable: Identifies whether the company signed } \\
\text { partnership agreements for marketing }\end{array}$ & $(+)$ \\
\hline $\begin{array}{l}\text { Technological_ } \\
\text { Network }\end{array}$ & $\begin{array}{l}\text { Dummy variable: Identifies whether the firm engaged in } \\
\text { technological collaboration agreements }\end{array}$ & $(+)$ \\
\hline \multicolumn{3}{|l|}{ Control Variables } \\
\hline Second_Generation & Second generation dummy variable & $(+)$ \\
\hline Foreign_Ownership & $\%$ Share of foreign capital & $(+)$ \\
\hline 1_Size & Logarithm of the number of employees & $(+)$ \\
\hline 1_Productivity & $\begin{array}{l}\text { Logarithms of added value / number of hours effectively } \\
\text { worked. }\end{array}$ & $(+)$ \\
\hline Human_Resources & $\%$ Of total personnel trained & $(+)$ \\
\hline Debt & Ratio of total debts over total liabilities & $(-)$ \\
\hline
\end{tabular}




\section{Independent Variables}

A network is defined as " $a$ set of two or more connected business relationships, in which each exchange relation is between business firms that are conceptualized as collective actors" (Chetty and Blankenburg Holm 2000, p. 79).

There are different types of collaboration networks. For the purpose of this study we consider commercial and technological collaboration. So, following Ghauri, Lutz, and Tesfom (2003) we define Commercial collaboration as vertical collaboration with clients and/or suppliers which allows a firm to gain considerable knowledge about new technologies, markets and users' needs (Whitley 2002). According to Ghauri, Lutz, and Tesfom (2003) a commercial network is an opportunity for firms to participate in the international market for a variety of reasons. First, a "capacity" reason, to meet unexpected or exceptional increases in demand, it means normally short-lived and unstable agreements. By contrast, the "specialized" agreement is longer-term and enduring-established by the principal to access specialized expertise or technology, which is not available inhouse. Finally, "economic" reason, the collaboration is established where cost benefits can be obtained by outsourcing parts of the production process. In all cases, outsourcing provides the principal with a greater degree of flexibility over its operations. In general, it can be said that commercial collaboration helps both participants to improve the quality and/ or the quantity of their products in order to be successful in export markets.

Another type of collaboration is the Technological collaboration defined by Nieto and Santamaría (2010) as alliances that "include collaborative $R \& D$ agreements, university and/or research institute agreements and technology licensing". Firms use technological collaboration for information exchange, resource acquisition, technology transfer and risk management (Nieto and Santamaría 2010). To be competitive in foreign markets, firms need to innovate constantly (Veugelers and Cassiman 1999) and technological collaboration could enable FFs to overcome their lack of resources and capabilities, so this type of collaboration would boost the internationalization of the firm.

In order to analyse the effect of networks on the internationalization process, we have included two different measures regarding networks.

On the one hand, Commercial collaboration (Commercial_ Networks) is a dichotomous variable that takes value one if firm $i$ participated in year $t$ in commercial agreements with wholesalers and retailers, and zero if it did not.

On the other hand, Technological collaboration (Technological__Networks) is a dichotomous variable that indicates if the family firm has a collaborative agreement with wholesalers, competitors, retailers, universities or 
technological institutions to develop innovations.

\section{Control Variables}

We include some variables representing family firm characteristics. On one the hand, we consider a second and subsequent-generation family when the firm is more than 30 years old, following Fernández and Nieto (2005). The literature has shown that the attitudes and behaviors of family firms can vary throughout generations (Swinth and Vinton 1993; Welch 1992). Each generation of leadership brings new strategic ideas that build on underlying, long-held competencies developed by earlier strategies (Ward 1998). Second generations can be expected to be more qualified, and we must remember that the owner's background (training, language, international experience) has an influence on the decision to internationalize (Brush 1992). Following Fernández and Nieto $(2005,2006)$ the variable Second_Generation represents family firms which are more than 30 years old. We expect a positive effect of the second generation (and subsequent) management on export intensity.

On the other hand, we identify if a family firm is also owned by foreign capital. Family firms having another foreign company as a large shareholder are in a better position to develop their own resources, and in some circumstances they can even access the shareholder's resources (Fernández and Nieto 2005). Another company as a shareholder allows the family firm to enhance its internationalization process and acquire deeper foreign market knowledge. In other words, foreign ownership reduces uncertainty and the perceived risk (Bijmolt and Zwart 1994).Foreign_Ownership is calculated as the percentage of direct or indirect foreign capital in the share capital of the company participation. We expect a positive effect on export intensity.

We also consider the size because larger family firms may exhibit higher internationalization (Casillas and Acedo 2005). In line with Cesinger, Hughes, Mensching, Bouncken, Fredrich, and Kraus (2016), the empirical model includes the firm's size (Size) approximated using the number of employees' logarithm.

The model includes Productivity approximated by added value divided by the approximate number of hours effectively worked. The units of the hourly productivity measure may be interpreted in terms of thousands of Euros per $1000 \mathrm{~h}^{1}$. This measure also considered firms with non-negative added values. A positive influence on export intensity is expected. The literature provides two fundamental theories. First, the self-selection hypothesis argues that more productive firms are more likely to export because the level of competition in export markets is more intense, as these markets have higher costs than domestic markets (Wagner 2007). Second, according to the

\footnotetext{
${ }^{1}$ Although productivity is usually measured by the total factor productivity (TFP) index (Delgado, Farinas, and Ruano 2002), the TFP estimation can have correlation problems between the firms' productivity levels and input choices because profit-maximizing firms may adjust their input levels each time they notice productivity shocks (Silva, Afonso, and Africano 2012). To avoid these problems, we follow the recommendations of Wagner (2002) and Silva, Afonso, and Africano (2012) and measure productivity by using the labour productivity.
} 
sequential internationalization models, the learning-by-exporting effect was generated by export activities. The exporters develop new configurations of their resources and capabilities (Johanson and Vahlne 1977). Some recent studies show that these two explanations are complementary and not mutually exclusive (Wagner 2007; García and Avella 2008).

The model includes the firm's Human Resources, by means of employee training, calculated as a proportion of the firm's employees with a university degree (percentage of engineers and other graduates out of the staff total), in line with authors such as Plechero and Chaminade (2010), who also adopted this measure as a proxy of human capital. Human_Resources variable is therefore, expected to have a positive effect on export intensity.

The debt level of the firm (Debt) is measured by the ratio of outside debt to the total liabilities. This ratio explains how the company can finance their activity with their own resources and what degree of dependency lies with external agents. There is a consensus among authors that family firms prefer, primarily, self-financing and reinvesting profits to any other source of financing (Corbetta 1995; Poutziouris 2001). Therefore, Debt is expected to have a negative effect on exporting as Benito-Hernández, Priede-Bergamini, and Lopez-CozarNavarro (2014) show for a sample of Spanish family firms.

Finally, we control sector heterogeneity with a dummy variable for each Sector following previous studies such as Fernández and Nieto (2005).

The following table (Table 1) contains a description of the variables used in the models and the expected sign and the trend across quantiles.

\section{Descriptive Statistics}

The empirical study uses a longitudinal panel from 2006 to 2012 that consists of a total of 1,572 family firms. Of these, 965 family groups were exporters and make the unbalanced panel as used in the second stage. Table 2 shows that the average export intensity ratio stands at 26.37 percent. Meanwhile, family firms that export have on average 100 workers (69.75 for the entire sample, exporters and non-exporters). The hourly labour productivity is at 27.02 (23.60 for the entire sample) and only six percent of its employees has advanced training (4.7 percent for the entire sample). 
Table 2

Summary Statistics for Family Exporters

\begin{tabular}{lccccc}
\hline Variable & Total & Mean & $\begin{array}{l}\text { Standard } \\
\text { Deviation }\end{array}$ & Minimum & Maximum \\
\hline Export_Intensity & 3845 & 0.2637 & 0.2718 & 0.0001 & 1 \\
\hline Commercial_Network & 3458 & 0.3155 & 0.4647 & 0 & 1 \\
Technological 1_Network & 3848 & 0.3321 & 0.4710 & 0 & 1 \\
Second_Generation & 3454 & 0.3914 & 0.4881 & 0 & 1 \\
Foreign_Ownership & 3848 & 2.7300 & 0.1517 & 0 & 100 \\
Size & 3848 & 100.3930 & 208.5579 & 1 & 3536 \\
Productivity & 3807 & 27.0291 & 17.5051 & 0 & 237.4 \\
Human_Resources & 3459 & 6.1500 & 0.8016 & 0 & 100 \\
Debt & 3777 & 0.5340 & 0.2344 & 0.051 & 0.9997 \\
\hline
\end{tabular}

With regards to the variables relating to collaborative networks, it appears that family firms analysed are likely to participate in collaborative networks, collaborating in R \& $\mathrm{D}$ (technological networks) around 33.21 percent (20.59 percent for the entire sample) and a 31.55 percent signs stable marketing agreements ( 23.39 percent for the entire sample).

As for the direction of the family firm, 39.14 percent of the companies is run by the second generation (29.91 percent for the entire sample). On the other hand, the average share of foreign capital in the ownership of the family firm is around 2.73 percent (1.56 percent for the entire sample).

\section{Empirical Analysis}

The econometric strategy employed consists of estimating a dynamic Heckman-Probit model that can control for selection bias. Two equations are estimated for that purpose: the first includes the determinants of firms' decision to export, while the second considers the determinants of export intensity (percentage of export sales over total sales).

Roberts and Tybout (1997), Bernard and Jensen (2004), and Bernard, Jensen, Redding, and Schott (2012) describe the firm's decision to export as the result of a series of the firm's individual characteristics and the specific costs of entering each target market. Based on this idea, this study considers that the likelihood of exporting depends on firms' internal characteristics. The first equation is estimated using a probabilistic model 
(Probit). This analyses the factors affecting the likelihood of exporting and also provides the inverse Mills ratio ${ }^{2}$ for each firm and target.

$$
D_{i, t}^{\exp }=\left\{\begin{array}{l}
1\left(\exp \Rightarrow P\left(D_{i, t}=1\right)=f(\text { Networks+ ControWariables })\right. \\
o(\text { no-exp }) \text { in othercase }
\end{array}\right.
$$

Where the dependent variable ( $D_{i, t}^{\exp }$ ) is a fictitious variable taking the value one if firm $i$ exported in year $t$ and zero otherwise.

The second stage of the Heckman model analyses the determinants of export intensity. This equation is estimated employing a simultaneous quantile regression that provides the challenge to describe the effect of export factors at different points of the degree of internationalization. Standard linear regression techniques summarize the average relationship between network collaboration and export intensity. This provides only a partial view of the relationship. However, we are interested in describing the relationship at different points in the conditional distribution and the quantile regression provides that capability. In addition, quantile regression is more robust to outliers than least squares regression, and is semiparametric, avoiding assumptions about the parametric distribution of the error process (Conley and Galenson 1998). Moreover, the possible selection bias has been corrected at this stage using the inverse Mills ratio calculation, as seen in the equation (2):

$$
\begin{aligned}
& Q\left(\text { Export_Intensity }_{i t}\right)=\beta_{1}+\beta_{2} \text { Commercial_Networks }_{i t}+\beta_{3} \text { Technological_Networks }_{i t}+ \\
& +\beta_{4} \text { Second_Generation }_{i t}+\beta_{5} \text { Foreign_Ownership }_{i t}+\beta_{6} \text { l_Size }_{i t}+ \\
& +\beta_{7} l_{-} \text {Productivity }_{j t}+B_{8} \text { HumanResources }_{i t}+B_{9} \text { Debt }_{i t}+ \\
& + \text { InverseMills }+ \text { Sector }+ \text { Year }+U_{i j t}
\end{aligned}
$$

The dependent variable in this second stage is the firm's export value to total sales in year $t$ $\left(\right.$ Export_Intensity $\left._{i t}\right)$. Since the objective is to analyze the influence of cooperation between firms in export intensity, taking into account the different levels of export intensity, Commercial_Networks $s_{i t}$ and Technological_ Networks $i_{i t}$ are introduced as networks collaborations. The empirical model includes as control variables: Second Generation, Foreign Ownership, Firm Size, Productivity, Human capital and Indebtedness. Finally, the model includes Sector, a dummy for each industry to control sectorial heterogeneity and also Year, as a temporal dummy for each year.

\footnotetext{
${ }^{2}$ The inverse Mills ratio, named after John P. Mills, is the ratio of the probability density function to the cumulative distribution function of a distribution. Heckman (1979) proposed a two-stage estimation procedure using the inverse Mills ratio to take the selection bias into account. In the first step, a regression for observing a positive outcome of the dependent variable is modelled with a probit model. The inverse Mills ratio must be generated from the estimation of a probit model; a logit cannot be used. The probit model assumes that the error term follows a standard normal distribution. The estimated parameters are used to calculate the inverse Mills ratio, which is then included as an additional explanatory variable in the OLS estimation.
} 


\section{Results}

Before producing the estimations of the models described in the previous section, a preliminary analysis was conducted to determine the relationships between each of the independent explanatory variables used in the regression models. Table 3 shows the correlation matrix for each of the independent variables ${ }^{3}$.

Table 3

Spearman Correlations for each of the Independent Variables Used

\begin{tabular}{|c|c|c|c|c|c|c|c|c|c|}
\hline & 1 & 2 & 3 & 4 & 5 & 6 & 7 & 8 & $\overline{9}$ \\
\hline 1 Export_Intensity & 1 & & & & & & & & \\
\hline 2.Commercial_Network & $0.068^{*}$ & 1 & & & & & & & \\
\hline 3.Technological_Network & $0.192 *$ & $0.148^{*}$ & 1 & & & & & & \\
\hline 4.Second_Generation & $0.114 *$ & $0.065^{*}$ & $0.147 *$ & 1 & & & & & \\
\hline 5.Foreign_Ownership & $0.092 *$ & -0.007 & $0.065^{*}$ & $0.067 *$ & 1 & & & & \\
\hline 6.Size & $0.262 *$ & $0.269 *$ & $0.385^{*}$ & $0.239^{*}$ & $0.186^{*}$ & 1 & & & \\
\hline 7.Productivity & $0.188^{*}$ & 0.028 & $0.232 *$ & $0.106^{*}$ & $0.098^{*}$ & $0.250^{*}$ & 1 & & \\
\hline 8.Human_Resources & $0.174 *$ & $0.086^{*}$ & $0.279 *$ & $0.119^{*}$ & $0.066^{*}$ & $0.170^{*}$ & $0.312 *$ & 1 & \\
\hline 9.Debt & 0.008 & -0.004 & $-0.035^{*}$ & $-0.193 *$ & $0.047 *$ & 0.021 & $-0.171^{*}$ & -0.015 & 1 \\
\hline
\end{tabular}

*Significant at the 5\% level (Observations 3.356)

The first stage of the Heckman model is shown in the second column of Table 4 which presents the regression results of random effect Probit. The results support the positive effect of different types of networks' participation (commercial and technological networks) on export status of family firms. This result supports hypothesis one as the participation in networks has a positive effect on export status.

Also, it shows that the family's second generation, the equity of foreign partners, size, productivity and human resources are factors that favour the internationalization of family firms.

\footnotetext{
${ }^{3}$ The Kolmogorov-Smirnov test shows that variables do not show normality in distribution. Consequently, we cannot employ Pearson's correlations using Spearman's correlations.
} 
Table 4

Effects of Networks on the Family Export Status and Intensity

\begin{tabular}{|c|c|c|c|c|c|}
\hline \multirow[b]{3}{*}{ Variable } & \multirow{2}{*}{$\begin{array}{l}\text { First Stage } \\
\text { Probit }\end{array}$} & \multicolumn{3}{|c|}{ Second Stage } & \multirow{3}{*}{$\begin{array}{l}\text { Random- } \\
\text { Effects } \\
\text { Regression }\end{array}$} \\
\hline & & & & & \\
\hline & Regression & QR25 & QR50 & QR75 & \\
\hline \multirow{2}{*}{ Commercial_Network } & $0.3772 * *$ & $0.0080^{*}$ & 0.0160 & 0.0242 & 0.0063 \\
\hline & $(0.1760)$ & $(0.0043)$ & $(0.0064)$ & $(0.0203)$ & $(0.0081)$ \\
\hline \multirow{2}{*}{ Technological_Network } & $0.8170 * * *$ & $0.0117 * *$ & $0.0217 *$ & 0.0154 & 0.0063 \\
\hline & $(0.1767)$ & $(0.0057)$ & $(0.0099)$ & $(0.0232)$ & $(0.0070)$ \\
\hline \multirow{2}{*}{ Second_Generation } & $0.5567 * *$ & 0.0074 & $0.0227 * *$ & 0.0285 & $0.0242 * *$ \\
\hline & $(0.1894)$ & $(0.0048)$ & $(0.0103)$ & $(0.0186)$ & $(0.0102)$ \\
\hline \multirow{2}{*}{ Foreign_Ownership } & $0.0416 * *$ & $0.0008 * * *$ & 0.0010 & $0.0014 * *$ & 0.0002 \\
\hline & $(0.0120)$ & $(0.0001)$ & $(0.0009)$ & $(0.0005)$ & $(0.0002)$ \\
\hline \multirow{2}{*}{ 1_Size } & $1.6417 * * *$ & $0.0179 * * *$ & $0.0530 * * *$ & $0.0657 * * *$ & $0.0416 * * *$ \\
\hline & $(0.1108)$ & $(0.0032)$ & $(0.0092)$ & $(0.0138)$ & $(0.0075)$ \\
\hline \multirow{2}{*}{ 1_Productivity } & $0.5903 * * *$ & $0.0126 * *$ & $0.0417 * * *$ & $0.0876 * * *$ & $0.0102 *$ \\
\hline & $(0.1026)$ & $(0.0049)$ & $(0.0092)$ & $(0.0153)$ & $(0.0088)$ \\
\hline \multirow{2}{*}{ Human_Resources } & $0.0362 * *$ & $0.0006^{*}$ & $0.0019 * *$ & $0.0030 *$ & 0.0000 \\
\hline & $(0.0106)$ & $(0.0003)$ & $(0.0009)$ & $(0.0015)$ & $(0.0004)$ \\
\hline \multirow{2}{*}{ Debt } & -0.4912 & $0.0125 *$ & $0.0432 * *$ & $0.0592 *$ & 0.0161 \\
\hline & $(0.3051)$ & $(0.0073)$ & $(0.0180)$ & $(0.0333)$ & $(0.0181)$ \\
\hline \multirow{2}{*}{ Inverse Mills } & & $0.0073 *$ & $0.0195 * *$ & -0.0005 & 0.0015 \\
\hline & $\ldots$ & $(0.0038)$ & $(0.0096)$ & $(0.0158)$ & $(0.0090)$ \\
\hline \multirow{2}{*}{ Constant } & $1.0497 * * *$ & $-0.1360 * * *$ & $-0.3449 * * *$ & $-0.4551 * * *$ & -0.0818 \\
\hline & $(0.1538)$ & $(0.0275)$ & $(0.0564)$ & $(0.0685)$ & $(0.0611)$ \\
\hline Sectoral dummy & $(+)^{* * *}$ & $(+)^{* * *}$ & $(+) * * *$ & $(+)^{* * *}$ & $(+)^{* * *}$ \\
\hline Temporal dummy & $(+)^{* * *}$ & $(+)^{* * *}$ & $(+)^{* * *}$ & $(+)^{* * *}$ & $(+)^{* * *}$ \\
\hline Obsrvations & 3356 & 3356 & 3356 & 3356 & 3356 \\
\hline Prob > chi2 & 0.00 & $\ldots$ & $\ldots$ & $\ldots$ & $\ldots$ \\
\hline Pseudo R2 & $\ldots$ & 0.0654 & 0.1370 & 0.197 & \\
\hline R-squared & $\ldots$ & $\ldots$ & $\ldots$ & $\ldots$ & 0.193 \\
\hline
\end{tabular}

Standard errors in parentheses; ***significant at the $1 \%, * *$ at the $5 \%, *$ at the $10 \%$ level

After this first stage the inverse Mills ratio was calculated which will be introduced in the second stage to correct the possible selection bias.

In the second stage, we estimate quantile regression to analyse the heterogeneous behaviour of collaborative networks in different stages of family firm`s process of internationalization. A detailed analysis of quantiles supports the second hypothesis of this paper. In early stages of the internationalization process, networks show a 
positive effect on internationalization. While FFs become more intensive in export volume, the effect of the collaboration with other firms will be gradually losing its influence.

The simultaneous quantile regression has been accomplished using the bootstrap method with 200 iterations and the following quantiles: 25 percent, 50 percent and 75 percent that are presented in the third, fourth and fifth columns in Table 4 (QR25, QR50, QR75). The results support hypothesis two as the participation in networks has a positive effect at the early stages of the internationalization process.

If we look at quantile 25 (QR25) we can see that the two variables that measure the effect of collaborative networks on export intensity (Commercial_Networks and Technological_Networks) have statistical significance and positive effect, implying that these collaborative networks are therefore one of the factors that favour the internationalization of family firms in the case of exporters of low intensity. On the other hand, it can be seen that the effect of collaborative networks is diluted in the highest quantiles (QR50 and QR75), which represent more intense exporters. In particular, the loss of significance of Commercial_Networks in QR50 is found while for the quantile QR75 it is not significant for any of the variables relating to collaborative networks (neither Commercial_Networks nor Technological_Networks).

Finally, the last column of Table 4 shows the results of the Random Effects Model ${ }^{4}$ in order to compare results with quantile regression. We see that the effect of network collaboration differs considerably compared to the results of the quantile regression. In the Random Effect Regression, both Commercial and Technological Collaboration Networks do not show statistical significant effects while the effects are positive and statistically significant in lower export intensity stages when we use quantile regression. This result corroborates the fact that pooled regressions provide only a partial view of the relationship. For that, quantile econometric strategy is particularly interesting to describe the relationship between networks and export performance at different points in the conditional distribution.

With regard to the control variables, overall, the results confirm that family firms in the second generation, those with foreign capital, larger, more productive companies and with borrowing capacity, as well as those with better trained staff are the most intense in exports.

\footnotetext{
${ }^{4}$ The estimation technique used is panel data, three types of panel data estimations are proposed: the first, ordinary least square with the grouped panel; the second and third consider the time variation by including random effects and fixed effects, respectively. To determine which of the three models is the most suitable, we firstly proposed the Breusch-Pagan LM test for random effects. This test makes it possible to select between the OLS estimation of the grouped panel and the estimation with random effects. After testing, we concluded that the random effects are relevant, and, therefore, the use of the estimation including them was preferable to the grouped panel estimation. Furthermore, the Hausman test demonstrated that the random-effect and fixed-effect estimators do not differ substantially and that the ramdom-effect model explains better the sources of variation and, therefore, it is more convenient than the fixed-effect model.
} 


\section{Discussion and Conclusions}

The international markets can be too complex to be addressed by the family firm alone. Family firms face resource constrains and the internationalization process is highly demanding. However, they have more opportunities to be successful in international markets by collaborating with commercial agreements or to develop innovations.

In this context, our study sheds more light on the role of collaboration networks in the FF internationalization process, especially important in the early stages of internationalization, it become less relevant when the FF already has experience in the international markets The empirical work has validated the hypothesis of positive influence of participation in different types of collaborative networks on export status for a sample of family firms. Moreover, the use of quantile regression provides the challenge to show the effect of collaboration networks on different grades of export intensity. Networks have the potential to be a good instrument to increase the export activity of the FF, and our results confirm that the role of networks is stronger in the earlier stages of the internationalisation process. According to Ghauri, Lutz, and Tesfom (2003), our results show that networks can be used to solve export problems concerning quality, organisational, financial or information problems and also the problems related to the export market or the industry.Thus, social capital which involves relationships between individuals or between organizations, facilitates collaboration between firms and may be critical in the internationalization process of the FFs, especially in the earlier stages of the internationalization process. Our paper is an effort to systematize the role of networks in the international field of FFs, and we suggest that knowledge and learning gained in networks may be crucial to the export activity, especially when the export intensity is low. The findings of this study suggest that networks make FFs more likely to internationalize their business, especially those family firms with lower export intensity.

In today's rapidly changing international business environment, few resources are permanently needed. A shift is moving us all from "possession" to "usage" (Czinkota, Ronkainen, and Kotabe 2009). This shift is giving rise to a resource-sharing paradigm. Firms have more opportunities to collaborate by commercial agreements or to develop innovations; this could be the way for the future. This paper has implications for politicians, academics and managers. For governments because, following Graves and Thomas (2008), government grants can be a useful source of finance and knowledge for family firms in the early stages of internationalization, but they are not sufficient to build an internationalized family firm. For that, the participation in networks can be useful to those firms interested in international markets. The cases studied by Ghauri, Lutz, and Tesfom (2003) confirm that governments may act as sponsors for networking projects. However, politicians should not impose their 
strategies, but intervene on the basis of requests for help from the network. Also, governments can encourage such export collaboration, for example, an accumulation and subsequent sharing of benchmarking information.

Our results also have implications for managers. Managers are aware of the limitations in the case of FFs and they have to establish the needed mechanisms to compensate for them. One of these mechanisms is the establishment of collaboration networks with other firms (Johanson and Vahlne 2009). As indicated by the results of the study, membership in collaborative networks favours the export activity of the family firm, especially in companies with low export intensity. Therefore, it would be advisable that family firms have family members who enjoy international travel and it is also be important to select family firm members who are competent at networking and who are able to present the firm overseas favourably, especially in companies with low export intensity. In this regard, as a result of this work it might be advisable to encourage attendance at fairs, participation in trade associations, etc. by those family firms interested in expanding their international presence with the aim of creating networks that can promote their future export activities. It is critical that the requisite international business networks and marketing capabilities are developed (Graves and Thomas 2008).

Finally, the study presents academic implications. In this sense, the paper examines the effect of collaborative networks on exporting, paying attention to the different levels of export intensity. For that, we use an innovative methodology, quantile regression model, which allows us to analyze the influence of collaborative networks depending on export intensity.

\section{References}

Abdellatif M., B. Amann, and J. Jaussaud (2010). "Family versus Nonfamily Business: A Comparison of International Strategies," Journal of Family Business Strategy, 1, 108-115.

Anderson, A. R., S. L. Jack, and S. D. Dodd (2005). "The Role of Family Members in Entrepreneurial Networks: beyond the Boundaries of the Family Firm," Family Business Review, 18 (2), 135-154.

Arregle, J. L., M. A. Hitt, D. G. Sirmon, and P. Very (2007). "The Development of Organizational Social Capital: Attributes of Family Firms," Journal of Management Studies, 44 (1), 73-95.

Baum, J. A., T. Calabrese, and B.S. Silverman (2000). "Don’t Go It Alone: Alliance Network Composition and Startups Performance in Canadian Biotechnology,” Strategic Management Journal, 21, 267-294.

Benavides-Velasco, C. A., C. Quintana-García, and V. F. Guzmán-Parra (2013). “Trends in Family Business Research," Small Business Economics, 40 (1), 41-57. 
Benito-Hernández, S., T.Priede-Bergamini, and C. Lopez-Cozar-Navarro (2014). "Factors Determining Exportation and Internationalization in Family Businesses: the Importance of Debt," South African Journal of Business Management, 45 (1), 13-25.

Bernard, A., and B. Jensen (2004). "Why Some Firms Export," Review of Economics and Statistics, 86 (2), 561569.

Bernard A. G., J. B. Jensen, S. J. Redding, and P. K. Schott (2012). “The Empirics of Firm Heterogeneity and International Trade," The Annual Review of Economics, 4, 283-313.

Bijmolt, T. H., and P. S. Zwart (1994). "The Impact of Internal Factors on the Export Success of Dutch Small and Medium-Sized Firms,” Journal of Small Business Management, 32 (2), 69-83.

Brush, C. G. (1992). "Factors Motivating Small Companies to Internalize the Effect of Firm Age”. Unpublished Ph.D. dissertation, Boston University.

Brydon, K., and L. O. P. Dana (2011). "Globalisation and Firm Structure: Comparing a Family-Business and a Corporate Block Holder in the New Zealand Seafood Industry," International Journal of Globalisation and Small Business, 4 (2), 206-220.

Burt, R. S. (1997). “A Note on Social Capital and Network Content,” Social networks, 19 (4), 355-373.

Byrom, J., and K. Lehman (2009). "Coopers Brewery: Heritage and Innovation within a Family Firm," Marketing Intelligence \& Planning, 27 (4), 516-523.

Calabrò, A., and D. Mussolino (2013). "How Do Boards of Directors Contribute to Family SME Export Intensity? The Role of Formal and Informal Governance Mechanisms," Journal of Management \& Governance, 17 (2), 363-403.

Casillas, J.C., and F. J. Acedo (2005). "Internationalisation of Spanish family SMEs: an Analysis of Family Involvement," International Journal of Globalisation and Small Business, 1, 134-151.

Cesinger, B., M. Hughes, H. Mensching, R. Bouncken, V. Fredrich, and S. Kraus (2016). “A socioemotional Wealth Perspective on How Collaboration Intensity, Trust, and International Market Knowledge Affect Family Firms’ Multinationality,” Journal of World Business, 51 (4), 586-599.

Chetty, S., and D. Blankenburg Holm (2000). "Internationalisation of Small to Medium-Sized Manufacturing Firms: A Network Approach,” International Business Review, 9 (1), 77-93. 
Claver, E., L. Rienda, and D. Quer (2009). “Family Firms’ International Commitment: The Influence of FamilyRelated Factors," Family Business Review, 22 (2), 125-135.

Conley, T. G., and D. W. Galenson (1998). "Nativity and Wealth in Mid-Nineteenth-Century Cities," The Journal of Economic History, 58 (02), 468-493.

Corbetta, G. (1995). "Patterns of Development of Family Businesses in Italy," Family Business Review, 8(4), $255-265$.

Coviello, N. E. (2006). “The Network Dynamics of International New Ventures," Journal of International Business Studies, 37 (5), 713-731.

Coviello, N., and H. Munro (1997). "Network Relationships and the Internationalisation Process of Small Software Firms," International Business Review, 6 (4), 361-386.

Crick, D., R. Bradshaw, and S. Chaudhry (2006). "Successful Internationalising UK Family and Non-FamilyOwned Firms: A Comparative Study,” Journal of Small Business and Enterprise Development, 13 (4), 498-512.

Czinkota, M., I. Ronkainen, and M. Kotabe (2009). Emerging trends, threats, and opportunities in international marketing. International Business Collection. New York, Eds.: S. Tamer Cavusgil, Michael Czinkota, and Gary Knight.

Delgado, M. A., J. C. Farinas, and S. Ruano (2002). "Firm Productivity and Export Markets: A Non-Parametric Approach," Journal of International Economics, 57 (2), 397-422.

Donckels, R., and E. Frohlich (1991). “Are Family Businesses Really Different? European Experiences from STRATOS," Family Business Review, 4 (2), 149-160.

Dyer, J. H., and H. Singh (1998). “The Relational View: Cooperative Strategy and Sources of Interorganizational Competitive Advantage," Academy of Management Review, 23 (4), 660-679.

Estrin,S., K. Meyer, M. Wright, and F. Foliano (2008). "Export Propensity and Intensity of Subsidiaries in Emerging Economies,” International Business Review, 17 (5), 574-586.

Fernández, Z., and M. J. Nieto (2005). "Internationalization Strategy of Small and Medium-Sized Family Businesses: Some Influential Factors,” Family Business Review, 18(1), 77-89. 
Fernández, Z., and M. J. Nieto. (2006). "Impact of Ownership on the International Involvement of SMEs," Journal of International Business Studies, 37 (3), 340-351.

Gallo, M. A., and C. García Pont (1996). "Important Factors in Family Business Internationalization," Family Business Review, 9 (1), 45-59.

García, F., and L. Avella (2008). "La Influencia de la Exportación sobre los Resultados Empresariales: Análisis de las Pymes Manufactureras Españolas en el Período 1990-2002," Revista Europea de Dirección y Economía de la Empresa, 17 (2), 85-104.

Ghauri, P., C. Lutz, and G. Tesfom (2003). "Using Networks to Solve Export-Marketing Problems of Small and Medium-Sized Firms from Developing Countries,” European Journal of Marketing, 37 (5-6), 728-752.

Gómez-Mejía, L. R., K. T. Haynes, M. Nuñez-Nickel, K. L. Jacobson, and J. M. Moyano-Fuentes (2007). "Socioemotional Wealth and Business Risks in Family-Controlled Firms: Evidence from Spanish Olive Oil Mills," Administrative Science Quarterly, 52 (1), 106-137.

Graves, C., and J. Thomas (2004). "Internationalisation of the Family Business: A Longitudinal Perspective," International Journal of Globalisation and Small Business, 1 (1), 7-27.

Graves, C., and J. Thomas (2006). "Internationalization of Australian Family Business: A Managerial Capabilities Perspective," Family Business Review, 19, 207-224.

Graves, C., and J. Thomas (2008). "Determinants of the Internationalization Pathways of Family Firms: An Examination of Family Influence,” Family Business Review, 21 (2), 151-167.

Guner, B., J. Lee, and H. Lucius (2010). "The Impact of Industry Characteristics on Export Performance: A Three Country Study," International Journal of Business and Economics Perspectives, 5 (2), 126-141.

Hagedoorn, J. (2002). “Inter-firm R\&D Partnerships-An Overview of Pattern and Trends since 1960,” Research Policy, 31, 477-492.

Heckman, J. J. (1979). “Sample Selection Bias as a Specification Error,” Econometrica, 47 (1), 153-16.

Hitt, M. A., R. D. Ireland, S. M. Camp, and D. L. Sexton (2001). "Strategic Entrepreneurship: Entrepreneurial Strategies for Wealth Creation,” Strategic Management Journal, 22 (6-7), 479-491. 
Hitt, M. A., R. D. Ireland, S. M. Camp, and D. L. Sexton (2002). "Strategic Entrepreneurship: Integrating Entrepreneurial and Strategic Management Perspectives," Strategic entrepreneurship: Creating a new mindset, 1-16.

Johanson, J., and J. E. Vahlne (1977). "The Internationalization Process of the Firm: A Model of Knowledge Development on Increasing Foreign Commitments,” Journal of International Business Studies, 8 (1), 23-32.

Johanson, J., and J. E. Vahlne (1990). “The Mechanism of Internationalisation,” International Marketing Review, 7 (4), 11-24.

Johanson, J., and J. E. Vahlne (2009). “The Uppsala Internationalization Process Model Revisited: From Liability of Foreignness to Liability of Outsidership," Journal of International Business Studies, 40, 1411-1431.

Johanson, J., and L. G. Mattsson (1988). "Internationalization in Industrial Systems -A Network Approach. In: The Internationalization of the Firm: A Reader. Eds. P. J. Buckley and P. N. Ghauri. London, Academic Press, 303-321.

Kontinen, T., and A. Ojala (2011a). "Social Capital in the International Operations of Family SMEs," Journal of Small Business and Enterprise Development, 19 (1), 39-55.

Kontinen, T., and A. Ojala (2011b). "Networks Ties in the International Opportunity Recognition of Family SMEs,” International Business Review, 20, 440-453.

Leonidou, L.C., and C. S. Katsikeas (1996). “The Export Development Process: An Integrative Review of Empirical Models,” Journal of International Business Studies, 27(3), 517-551.

Majocchi, A., E. Bacchiocchi, and U. Mayrhofer (2005). "Firm Size, Business Experience and Export Intensity in SMEs: A Longitudinal Approach to Complex Relationships,” International Business Review, 14, $719-738$

Menéndez-Requejo, S. (2005). "Growth and Internationalization of Family Business,” International Journal of Globalisation and Small Business, 1, 122-133.

Merino, F., and V. Salas (2002). "Causes and Consequences of Exports' Channel Integration,” Spanish Economic Review, 4 (4), 239-259. 
Merino, F., J. Monreal-Pérez, and G. Sánchez-Marín (2014). "Family SMEs' Internationalization: Disentangling the Influence of Familiness on Spanish Firms' Export Activity," Journal of Small Business Management, article first published online, DOI: 10.1111/jsbm.12111.

Mínguez R. (2010). “La Cooperación para la Internacionalización como Estrategia de Expansión Exterior de la PYME,” Economía Industrial, 375, 113-124.

Mustafa, M., and S. Chen (2010). "The Strength of Family Networks in Transnational Immigrant Entrepreneurship," Thunderbird International Business Review, 52 (2), 97-106.

Nahapiet, J., and S. Ghoshal (1998). "Social Capital, Intellectual Capital, and the Organizational Advantage," Academy of Management Review, 23 (2), 242-266.

Nieto, M.J., and L. Santamaría (2010). "Technological Collaboration: Bridging the Innovation Gap between Small and Large Firms,” Journal of Small Business Management, 48 (1), 44-69.

Pearson, A.W., J.C. Carr, and J. C. Shaw (2008). "Towards a Theory of Familiness: A Social Capital Perspective," Entrepreneurship Theory and Practice, 32 (6), 949-969.

Pla-Barber, J., and J. Alegre (2007). “Analysing the Link between Export Intensity, Innovation and Firm Size in a Science-Based Industry," International Business Review, 16 (3), 275-293.

Plechero M., and C. Chaminade (2010). "From New to the Firm to New to the World. Effect of Geographical Proximity and Technological Capabilities on the Degree of Novelty in Emerging Economies," Paper No. 2010/12, Lund University, CIRCLE-Center for Innovation, Research and Competences in the Learning Economy.

Poutziouris, P. Z. (2001). "The Views of Family Companies on Venture Capital: Empirical Evidence from the UK Small to Medium-Size Enterprising Economy,” Family Business Review, 14 (3), 277-291.

Pukall, Th. J., and A. Calabrò (2014). "The Internationalization of Family Firms: A Critical Review and Integrative Model," Family Business Review, 27 (2), 103-125.

Reis, J., and R. Forte (2016). “The impact of Industry Characteristics on Firms' Export Intensity,” International Area Studies Review, 19 (3), 266-281.

Roberts, M., and J. Tybout (1997). What Makes Exports Boom, Washington, DC: The World Bank. 
Ruzzier, M., B. Antončič, and M. Konečnik (2006). "The Resource-Based Approach to the Internationalisation of SMEs: Differences in Resource Bundles between Internationalised and Non-Internationalised Companies," Zagreb International Review of Economics and Business, 9 (2), 95-116.

Sciascia, S., P. Mazzola, J. H. Astrachan, and T. M. Pieper (2013). "Family Involvement in the Board of Directors: Effects on Sales Internationalization,” Journal of Small Business Management, 51 (1), 83-99.

Segaro, E. (2012). "Internationalization of Family SMEs: The Impact of Ownership, Governance, and Top Management Team,” Journal of Management \& Governance, 16 (1), 147-169.

Serrano, R., I. Acero, and M. Fernández-Olmos (2016). "Networks and Export Performance of Agri-Food Firms: New Evidence Linking Micro and Macro Determinants,” Agricultural Economics (Zemědělská ekonomika), 62 (10), 459-470.

Silva, A., O. Afonso, and A. P. Africano (2012). "Which Manufacturing Firms Learn by Exporting?," The Journal of International Trade \& Economic Development, 21 (6), 773-805.

Sirmon, D. G., and M. A. Hitt. (2003). Managing Resources: Linking Unique Resources, Management, and Wealth Creation in Family Firms," Entrepreneurship Theory and Practice, 27 (4), 339-358.

Sorenson, R. L., C. A. Folker, and K. H. Brigham (2008). "The Collaborative Network Orientation: Achieving Business Success through Collaborative Relationships," Entrepreneurship Theory and Practice, 32 (4), 615-634.

Stein, J.C. (1989). "Efficient Capital Markets, Inefficient Firms: A Model of Myopic Corporate Behavior," The quarterly Journal of Economics, 104 (4), 655-669.

Swinth, R. L., and K. L. Vinton (1993). "Do Family-Owned Businesses Have a Strategic Advantage in International Joint Ventures?," Family Business Review, 6 (1), 19-30.

Veugelers, R., and B. Cassiman (1999). "Make or Buy in Innovation Strategies: Evidence from Belgian Manufacturing Firms," Research Policy, 28, 63-80.

Wagner, J. (2002). "The Causal Effects of Exports on Firm Size and Labor Productivity: First Evidence from a Matching Approach,” Economics Letters, 77 (2), 287-292.

Wagner, J. (2007). "Productivity and Size of the Export Market - Evidence for West and East German Plants," 2004. Working Paper Series in Economics, 43, University of Lüneburg, Institute of Economics. 
Ward, J. L. (1998). "Growing the Family Business: Special Challenges and Best Practices," Family Business Review, 10, 323-337.

Welch, L. S. (1992). "The Use of Alliances by Small Firms in Achieving Internationalization,” Scandinavian International Business Review, 1 (2), 21-37.

Whitley, R. (2002). "Developing Innovative Competences: The Role of Institutional Frameworks," Industrial and Corporate Change, 11, 497-528.

Wright, P. C., and W. Nasierowski (1994). "The Expatriate Family Firm and Cross-Cultural Management Training: A Conceptual Framework," Human Resource Development Quarterly, 5 (2), 153-167.

Zaefarian, R., T. Y. Eng, and M. Tasavori (2016). “An Exploratory Study of International Opportunity Identification among Family Firms," International Business Review, 25 (1B), 333-345.

Zahra, S.A. (2003). "International Expansion of U.S. Manufacturing Family Business: The Effect of Ownership and Involvement," Journal of Business Venturing, 18 (4), 495-512.

Zaniewska, K. (2012). “Determinants of Family Business Internationalization: Review of Existing Research,” Journal of Applied Economics, 31 (2), 52-60. 


\section{DOCUMENTOS DE TRABAJO}

Facultad de Economía y Empresa

Universidad de Zaragoza

Depósito Legal Z-1411-2010. ISSN 2171-6668

2002-01: "Evolution of Spanish Urban Structure During the Twentieth Century". Luis Lanaspa, Fernando Pueyo y Fernando Sanz. Department of Economic Analysis, University of Zaragoza.

2002-02: "Una Nueva Perspectiva en la Medición del Capital Humano". Gregorio Giménez y Blanca Simón. Departamento de Estructura, Historia Económica y Economía Pública, Universidad de Zaragoza.

2002-03: "A Practical Evaluation of Employee Productivity Using a Professional Data Base". Raquel Ortega. Department of Business, University of Zaragoza.

2002-04: "La Información Financiera de las Entidades No Lucrativas: Una Perspectiva Internacional". Isabel Brusca y Caridad Martí. Departamento de Contabilidad y Finanzas, Universidad de Zaragoza.

2003-01: "Las Opciones Reales y su Influencia en la Valoración de Empresas". Manuel Espitia y Gema Pastor. Departamento de Economía y Dirección de Empresas, Universidad de Zaragoza.

2003-02: "The Valuation of Earnings Components by the Capital Markets. An International Comparison". Susana Callao, Beatriz Cuellar, José Ignacio Jarne and José Antonio Laínez. Department of Accounting and Finance, University of Zaragoza.

2003-03: "Selection of the Informative Base in ARMA-GARCH Models". Laura Muñoz, Pilar Olave and Manuel Salvador. Department of Statistics Methods, University of Zaragoza.

2003-04: "Structural Change and Productive Blocks in the Spanish Economy: An Imput-Output Analysis for 1980-1994”. Julio Sánchez Chóliz and Rosa Duarte. Department of Economic Analysis, University of Zaragoza.

2003-05: "Automatic Monitoring and Intervention in Linear Gaussian State-Space Models: A Bayesian Approach". Manuel Salvador and Pilar Gargallo. Department of Statistics Methods, University of Zaragoza.

2003-06: "An Application of the Data Envelopment Analysis Methodology in the Performance Assessment of the Zaragoza University Departments”. Emilio Martín. Department of Accounting and Finance, University of Zaragoza.

2003-07: "Harmonisation at the European Union: a difficult but needed task". Ana Yetano Sánchez. Department of Accounting and Finance, University of Zaragoza.

2003-08: "The investment activity of spanish firms with tangible and intangible assets". Manuel Espitia and Gema Pastor. Department of Business, University of Zaragoza. 
2004-01: "Persistencia en la performance de los fondos de inversión españoles de renta variable nacional (1994-2002)”. Luis Ferruz y María S. Vargas. Departamento de Contabilidad y Finanzas, Universidad de Zaragoza.

2004-02: "Calidad institucional y factores político-culturales: un panorama internacional por niveles de renta”. José Aixalá, Gema Fabro y Blanca Simón. Departamento de Estructura, Historia Económica y Economía Pública, Universidad de Zaragoza.

2004-03: "La utilización de las nuevas tecnologías en la contratación pública". José $M^{a}$ Gimeno Feliú. Departamento de Derecho Público, Universidad de Zaragoza.

2004-04: "Valoración económica y financiera de los trasvases previstos en el Plan Hidrológico Nacional español". Pedro Arrojo Agudo. Departamento de Análisis Económico, Universidad de Zaragoza. Laura Sánchez Gallardo. Fundación Nueva Cultura del Agua.

2004-05: "Impacto de las tecnologías de la información en la productividad de las empresas españolas". Carmen Galve Gorriz y Ana Gargallo Castel. Departamento de Economía y Dirección de Empresas. Universidad de Zaragoza.

2004-06: "National and International Income Dispersión and Aggregate Expenditures". Carmen Fillat. Department of Applied Economics and Economic History, University of Zaragoza. Joseph Francois. Tinbergen Institute Rotterdam and Center for Economic Policy Resarch-CEPR.

2004-07: “Targeted Advertising with Vertically Differentiated Products". Lola Esteban and José M. Hernández. Department of Economic Analysis. University of Zaragoza.

2004-08: "Returns to education and to experience within the EU: are there differences between wage earners and the self-employed?". Inmaculada García Mainar. Department of Economic Analysis. University of Zaragoza. Víctor M. Montuenga Gómez. Department of Business. University of La Rioja

2005-01: "E-government and the transformation of public administrations in EU countries: Beyond NPM or just a second wave of reforms?". Lourdes Torres, Vicente Pina and Sonia Royo. Department of Accounting and Finance.University of Zaragoza

2005-02: "Externalidades tecnológicas internacionales y productividad de la manufactura: un análisis sectorial". Carmen López Pueyo, Jaime Sanau y Sara Barcenilla. Departamento de Economía Aplicada. Universidad de Zaragoza.

2005-03: "Detecting Determinism Using Recurrence Quantification Analysis: Three Test Procedures". María Teresa Aparicio, Eduardo Fernández Pozo and Dulce Saura. Department of Economic Analysis. University of Zaragoza.

2005-04: "Evaluating Organizational Design Through Efficiency Values: An Application To The Spanish First Division Soccer Teams". Manuel Espitia Escuer and Lucía Isabel García Cebrián. Department of Business. University of Zaragoza.

2005-05: "From Locational Fundamentals to Increasing Returns: The Spatial Concentration of Population in Spain, 1787-2000”. María Isabel Ayuda. Department of Economic Analysis. University of Zaragoza. Fernando Collantes and Vicente Pinilla. Department of Applied Economics and Economic History. University of Zaragoza. 
2005-06: "Model selection strategies in a spatial context". Jesús Mur and Ana Angulo. Department of Economic Analysis. University of Zaragoza.

2005-07: "Conciertos educativos y selección académica y social del alumnado". María Jesús Mancebón Torrubia. Departamento de Estructura e Historia Económica y Economía Pública. Universidad de Zaragoza. Domingo Pérez Ximénez de Embún. Departamento de Análisis Económico. Universidad de Zaragoza.

2005-08: "Product differentiation in a mixed duopoly". Agustín Gil. Department of Economic Analysis. University of Zaragoza.

2005-09: "Migration dynamics, growth and convergence". Gemma Larramona and Marcos Sanso. Department of Economic Analysis. University of Zaragoza.

2005-10: "Endogenous longevity, biological deterioration and economic growth". Marcos Sanso and Rosa María Aísa. Department of Economic Analysis. University of Zaragoza.

2006-01: "Good or bad? - The influence of FDI on output growth. An industry-level analysis". Carmen Fillat Castejón. Department of Applied Economics and Economic History. University of Zaragoza. Julia Woerz. The Vienna Institute for International Economic Studies and Tinbergen Institute, Erasmus University Rotterdam.

2006-02: "Performance and capital structure of privatized firms in the European Union". Patricia Bachiller y Ma José Arcas. Departamento de Contabilidad y Finanzas. Universidad de Zaragoza.

2006-03: "Factors explaining the rating of Microfinance Institutions". Begoña Gutiérrez Nieto and Carlos Serrano Cinca. Department of Accounting and Finance. University of Saragossa, Spain.

2006-04: "Libertad económica y convergencia en argentina: 1875-2000". Isabel Sanz Villarroya. Departamento de Estructura, Historia Económica y Economía Pública. Universidad de Zaragoza. Leandro Prados de la Escosura. Departamento de $\mathrm{H}^{\mathrm{a}}$ e Instituciones Ec. Universidad Carlos III de Madrid.

2006-05: "How Satisfied are Spouses with their Leisure Time? Evidence from Europe*”. Inmaculada García, José Alberto Molina y María Navarro. University of Zaragoza.

2006-06: "Una estimación macroeconómica de los determinantes salariales en España (1980-2000)". José Aixalá Pastó y Carmen Pelet Redón. Departamento de Estructura, Historia Económica y Economía Pública. Universidad de Zaragoza.

2006-07: "Causes of World Trade Growth in Agricultural and Food Products, 1951 - 2000". Raúl Serrano and Vicente Pinilla. Department of Applied Economics and Economic History, University of Zaragoza, Gran Via 4, 50005 Zaragoza (Spain).

2006-08: "Prioritisation of patients on waiting lists: a community workshop approach". Angelina Lázaro Alquézar. Facultad de Derecho, Facultad de Económicas. University of Zaragoza. Zaragoza, Spain. Begoña Álvarez-Farizo. C.I.T.A.- Unidad de Economía. Zaragoza, Spain 
2007-01: "Deteminantes del comportamiento variado del consumidor en el escenario de Compra". Carmén Berné Manero y Noemí Martínez Caraballo. Departamento de Economía y Dirección de Empresas. Universidad de Zaragoza.

2007-02: "Alternative measures for trade restrictiveness. A gravity approach". Carmen Fillat \& Eva Pardos. University of Zaragoza.

2007-03: "Entrepreneurship, Management Services and Economic Growth". Vicente Salas Fumás \& J. Javier Sánchez Asín. Departamento de Economía y Dirección de Empresas. University of Zaragoza.

2007-04: "Equality versus Equity based pay systems and their effects on rational altruism motivation in teams: Wicked masked altruism". Javier García Bernal \& Marisa Ramírez Alerón. University of Zaragoza.

2007-05: "Macroeconomic outcomes and the relative position of Argentina's Economy: 1875-2000". Isabel Sanz Villarroya. University of Zaragoza.

2008-01: "Vertical product differentiation with subcontracting". Joaquín Andaluz Funcia. University of Zaragoza.

2008-02: "The motherwood wage penalty in a mediterranean country: The case of Spain" Jose Alberto Molina Chueca \& Victor Manuel Montuenga Gómez. University of Zaragoza.

2008-03: "Factors influencing e-disclosure in local public administrations". Carlos Serrano Cinca, Mar Rueda Tomás \& Pilar Portillo Tarragona. Departamento de Contabilidad y Finanzas. Universidad de Zaragoza.

2008-04: "La evaluación de la producción científica: hacia un factor de impacto neutral". José María Gómez-Sancho y María Jesús Mancebón-Torrubia. Universidad de Zaragoza.

2008-05: "The single monetary policy and domestic macro-fundamentals: Evidence from Spain". Michael G. Arghyrou, Cardiff Business School and Maria Dolores Gadea, University of Zaragoza.

2008-06: "Trade through fdi: investing in services". Carmen Fillat-Castejón, University of Zaragoza, Spain; Joseph F. Francois. University of Linz, Austria; and CEPR, London \& Julia Woerz, The Vienna Institute for International Economic Studies, Austria.

2008-07: "Teoría de crecimiento semi-endógeno vs Teoría de crecimiento completamente endógeno: una valoración sectorial”. Sara Barcenilla Visús, Carmen López Pueyo, Jaime Sanaú. Universidad de Zaragoza.

2008-08: "Beating fiscal dominance. The case of spain, 1874-1998". M. D. Gadea, M. Sabaté \& R. Escario. University of Zaragoza.

2009-01: "Detecting Intentional Herding: What lies beneath intraday data in the Spanish stock market" Blasco, Natividad, Ferreruela, Sandra (Department of Accounting and Finance. University of Zaragoza. Spain); Corredor, Pilar (Department of Business Administration. Public University of Navarre, Spain). 
2009-02: "What is driving the increasing presence of citizen participation initiatives?". Ana Yetano, Sonia Royo \& Basilio Acerete. Departamento de Contabilidad y Finanzas. Universidad de Zaragoza.

2009-03: "Estilos de vida y "reflexividad" en el estudio del consumo: algunas propuestas". Pablo García Ruiz. Departamento de Psicología y Sociología. Universidad de Zaragoza.

2009-04: "Sources of Productivity Growth and Convergence in ICT Industries: An Intertemporal Non-parametric Frontier Approach". Carmen López-Pueyo and $\mathrm{M}^{\mathrm{a}}$ Jesús Mancebón Torrubia. Universidad de Zaragoza.

2009-05: "Análisis de los efectos medioambientales en una economía regional: una aplicación para la economía aragonesa”. Mónica Flores García y Alfredo J. Mainar Causapé. Departamento de Economía y Dirección de Empresas. Universidad de Zaragoza.

2009-06: "The relationship between trade openness and public expenditure. The Spanish case, 19602000”. Ma Dolores Gadea, Marcela Sabate y Estela Saenz. Department of Applied Economics. School of Economics. University of Economics.

2009-07: "Government solvency or just pseudo-sustainability? A long-run multicointegration approach for Spain". Regina Escario, María Dolores Gadea, Marcela Sabaté. Applied Economics Department. University of Zaragoza.

2010-01: "Una nueva aproximación a la medición de la producción científica en revistas JCR y su aplicación a las universidades públicas españolas”. José María Gómez-Sancho, María Jesús Mancebón Torrubia. Universidad de Zaragoza

2010-02: "Unemployment and Time Use: Evidence from the Spanish Time Use Survey". José Ignacio Gimenez-Nadal, University of Zaragoza, José Alberto Molina, University of Zaragoza and IZA, Raquel Ortega, University of Zaragoza.

2011-01: "Universidad y Desarrollo sostenible. Análisis de la rendición de cuentas de las universidades del G9 desde un enfoque de responsabilidad social”. Dr. José Mariano Moneva y Dr. Emilio Martín Vallespín, Universidad de Zaragoza.

2011-02: “Análisis Municipal de los Determinantes de la Deforestación en Bolivia.” Javier Aliaga Lordeman, Horacio Villegas Quino, Daniel Leguía (Instituto de Investigaciones Socio-Económicas. Universidad Católica Boliviana), y Jesús Mur (Departamento de Análisis Económico. Universidad de Zaragoza)

2011-03: "Imitations, economic activity and welfare". Gregorio Giménez. Facultad de Ciencias Económicas y Empresariales. Universidad de Zaragoza.

2012-01: "Selection Criteria for Overlapping Binary Models". M. T Aparicio and I. Villanúa. Department of Economic Analysis, Faculty of Economics, University of Zaragoza

2012-02: "Sociedad cooperativa y socio cooperativo: propuesta de sus funciones objetivo". Carmen Marcuello y Pablo Nachar-Calderón. Universidad de Zaragoza

2012-03: "Is there an environmental Kuznets curve for water use? A panel smooth transition regression approach". Rosa Duarte (Department of Economic Analysis), Vicente Pinilla (Department of 
Applied Economics and Economic History) and Ana Serrano (Department of Economic Analysis). Faculty of Economics and Business Studies, Universidad de Zaragoza

2012-04: "Análisis Coste-Beneficio de la introducción de dispositivos ahorradores de agua. Estudio de un caso en el sector hotelero". Barberán Ramón, Egea Pilar, Gracia-de-Rentería Pilar y Manuel Salvador. Facultad de Economía y Empresa. Universidad de Zaragoza.

2013-01: "The efficiency of Spanish mutual funds companies: A slacks - based measure approach". Carlos Sánchez González, José Luis Sarto and Luis Vicente. Department of Accounting and Finance. Faculty of Economics and Business Studies, University of Zaragoza.

2013-02: "New directions of trade for the agri-food industry: a disaggregated approach for different income countries, 1963-2000". Raúl Serrano (Department of Business Administration) and Vicente Pinilla (Department of Applied Economics and Economic History). Universidad de Zaragoza.

2013-03: "Socio-demographic determinants of planning suicide and marijuana use among youths: are these patterns of behavior causally related?". Rosa Duarte, José Julián Escario and José Alberto Molina. Department of Economic Analysis, Universidad de Zaragoza.

2014-01: "Análisis del comportamiento imitador intradía en el mercado de valores español durante el periodo de crisis 2008-2009”. Alicia Marín Solano y Sandra Ferreruela Garcés. Facultad de Economía y Empresa, Universidad de Zaragoza.

2015-01: "International diversification and performance in agri-food firms". Raúl Serrano, Marta Fernández-Olmos and Vicente Pinilla. Facultad de Economía y Empresa, Universidad de Zaragoza.

2015-02: "Estimating income elasticities of leisure activities using cross-sectional categorized data". Jorge González Chapela. Centro Universitario de la Defensa de Zaragoza.

2015-03: "Global water in a global world a long term study on agricultural virtual water flows in the world”. Rosa Duarte, Vicente Pinilla and Ana Serrano. Facultad de Economía y Empresa, Universidad de Zaragoza.

2015-04: "Activismo local y parsimonia regional frente a la despoblación en Aragón: una explicación desde la economía política". Luis Antonio Sáez Pérez, María Isabel Ayuda y Vicente Pinilla. Facultad de Economía y Empresa, Universidad de Zaragoza.

2015-05: "What determines entepreneurial failure: taking advantage of the institutional context". Lucio Fuentelsaz, Consuelo González-Gil y Juan P. Maicas. University of Zaragoza.

2015-06: "Factores macroeconómicos que estimulan el emprendimiento. Un análisis para los países desarrollados y no desarrollados". Beatriz Barrado y José Alberto Molina. Universidad de Zaragoza.

2015-07: "Emprendedores y asalariados en España: efectos de la situación financiera familiar y diferencias en salarios". Jorge Velilla y José Alberto Molina. Universidad de Zaragoza.

2016-01: "Time spent on cultural activities at home in Spain: Differences between wage-earners and the self-employed". José Alberto Molina, Juan Carlos Campaña and Raquel Ortega. University of Zaragoza. 
2016-02: "Human resource management practices and organizational performance. The mediator role of immaterial satisfaction in Italian Social Cooperatives". Silvia Sacchetti (University of Stirling), Ermanno C. Tortia (University of Trento) and Francisco J. López Arceiz (University of Zaragoza).

2016-03: "Exploration, exploitation and innovation performance: Disentangling environmental dynamism". Pilar Bernal (University of Zaragoza), Juan P. Maicas (University of Zaragoza) and Pilar Vargas (University of La Rioja).

2016-04: "Las relaciones comerciales contemporáneas de Aragón con Cataluña: de la complementariedad al modelo intraindustrial". Luis Germán Zubero (University of Zaragoza) y Vicente Pinilla (University of Zaragoza).

2016-05: "La demanda de agua urbana para actividades productivas. Un análisis con microdatos". Pilar Gracia de Rentería, Ramón Barberán y Jesús Mur. Universidad de Zaragoza.

2017-01: "Testing for breaks in the weighting matrix". Ana Angulo (University of Zaragoza), Peter Burridge (University of York) and Jesús Mur (University of Zaragoza).

2017-02: "Los determinantes del autosuministro de agua para actividades productivas en un entorno urbano. El caso del municipio de Zaragoza”. Pilar Gracia de Rentería, Ramón Barberán y Jesús Mur. Universidad de Zaragoza.

2017-03: "Subjective educational mismatch and signalling in Spain". Inmaculada García-Mainar and Víctor M. Montuenga-Gómez. University of Zaragoza.

2017-04: "Collaborative networks and export intensity in family firms: a quantile regression approach”. Raúl Serrano, Isabel Acero-Fraile and Natalia Dejo-Oricain. University of Zaragoza. 